$\begin{array}{ll}\text { Abstracta Iranica } & \begin{array}{l}\text { Abstracta Iranica } \\ \text { Revue bibliographique pour le domaine irano-aryen }\end{array} \\ & \text { Volume } \mathbf{3 1} \mid \mathbf{2 0 1 1} \\ & \text { Comptes rendus des publications de } \mathbf{2 0 0 8}\end{array}$

\title{
Jean de Dalyatha. Les Homélies I-XV. Antélias, CERO, 2007, 302 p. (Sources syriaques 2)
}

Florence Jullien

\section{(2) OpenEdition}

1 Journals

\section{Édition électronique}

URL : http://journals.openedition.org/abstractairanica/39666

DOI : 10.4000/abstractairanica.39666

ISSN : 1961-960X

Éditeur :

CNRS (UMR 7528 Mondes iraniens et indiens), Éditions de l'IFRI

\section{Édition imprimée}

Date de publication : 15 mai 2011

ISSN : 0240-8910

\section{Référence électronique}

Florence Jullien, « Jean de Dalyatha. Les Homélies I-XV. Antélias, CERO, 2007, 302 p. (Sources syriaques 2) », Abstracta Iranica [En ligne], Volume 31 | 2011, document 217, mis en ligne le 11 octobre 2012, consulté le 26 septembre 2020. URL : http://journals.openedition.org/abstractairanica/39666 ; DOI : https://doi.org/10.4000/abstractairanica.39666

Ce document a été généré automatiquement le 26 septembre 2020.

Tous droits réservés 


\title{
Jean de Dalyatha. Les Homélies I-XV. Antélias, CERO, 2007, 302 p. (Sources syriaques 2)
}

\author{
Florence Jullien
}

1 Ce deuxième volume de la collection Sources syriaques présente une édition critique du texte syriaque inédit des 15 premières Homélies, avec traduction, introduction et notes. Ce travail, réalisé par l'élève du plus éminent spécialiste de Jean de Dalyatha, Robert Beuley $(\dagger)$, nous donne accès à ce texte remarquable de la littérature ascétique et mystique du VIII ${ }^{\mathrm{e}}$. qui fleurit dans la région du Beth-Nouhadra et de Qardu.

\section{INDEX}

Thèmes : 6.3. Autres religions

\section{AUTEURS}

FLORENCE JULLIEN

EPHE - Paris 